\title{
Opinion
}

Occupational therapists are increasingly engaging in research. As this occurs, important and challenging questions are being asked about the most appropriate research approaches to use. Strongly held perspectives of what best constitutes evidence often conflict with influential hierarchies of research. The British Journal of Occupational Therapy has, in recent years, published a variety of papers and letters that have presented and defended effectively the differing perspectives of research approaches. Each of these has presented challenges to occupational therapy research. This opinion piece supports a combinist approach to research. It presents and defends such an approach from a subtle realist perspective.

\section{Subtle Realism and Occupational Therapy: an Alternative Approach to Knowledge Generation and Evaluation}

\author{
Edward A S Duncan and Margaret M Nicol
}

\section{Introduction}

The nature of knowledge and what best constitutes evidence to support practice have been topical features within recent years in the British Journal of Occupational Therapy (Bannigan 2002, Copley 2002, Hyde 2002, 2004, Legg and Walker 2002, MacLean and Jones 2002, Bryant 2004, Eva and Paley 2004). Authors have expressed strong views about the nature of evidence and its potential use and misuse in guiding clinicians' practice. Such debate is both inevitable and vital within a profession whose client-centred interventions have been recognised as complex (Creek 2003). This opinion piece develops the debate by exploring the potential relevance of a 'subtle realist' approach (Kirk Miller 1986, Hammersley 1992) to knowledge generation and evaluation. It is proposed that subtle realism offers a useful epistemology for occupational therapy research.

\section{Paradigms of inquiry}

A paradigm of inquiry essentially has three components (Hill Bailey 1997):

- The ontology (the nature of knowledge)

- The epistemology (the researcher's approach to the knowledge)

- The methodology (the chosen research strategy). Two general research styles differentiate the theoretical basis and the methodological approach to a problem: qualitative research, which focuses on the process, qualities and meanings of events, and quantitative research, which emphasises the analysis of causal relationships between variables and measurement. Each of these research styles finds its roots in positivistic and post-positivistic paradigms. However, during the development of qualitative research, several anti-positivistic paradigms have also emerged (Denzin and Lincoln 2000).

\section{Positivistic and post-positivistic paradigms} Positivism contends that there is an absolute reality, which can be measured, studied and understood. Traditionally, positivism is related to quantitative research. However, early qualitative research also emerged from a positivistic paradigm. Post-positivism states that an absolute reality can never be understood and may only be approximated (Denzin and Lincoln 2000).

\section{Anti-positivistic paradigms}

Not all theorists agree with the suppositions of positivistic and post-positivistic thinking. Many qualitative theorists view such structures as fundamentally restrictive and ignorant of alternative perspectives. This has led to the development of, amongst others, constructivist, interpretive and critical theory paradigms.

The fundamental bases of such approaches are that they propose multiple constructed realities, because different people are likely to experience the world in differing ways (Lincoln and Guba 2000). This, in turn, leads to radical scepticism regarding the possibilities for knowledge and a belief that research is only an interpretation of multiple realities (Henwood and Nicholson 1996). Such a belief may appear to support an occupational therapy approach 
to intervention because it seems to validate the professional values of individual worth and the uniqueness of each moment and activity. However, it is unhelpful in a health economic era, where resources are limited and monies are allocated to interventions that can demonstrate their worth.

\section{Quantitative or qualitative inquiry?}

Quantitative and qualitative inquiries have been viewed as incompatible (Lincoln 1990). The paradigmatic differences are unmistakable and researchers in each camp frequently dismiss the work of the other as either too biased or too superficial in understanding complex phenomena. However, the presentation of each paradigm as conflicting has been criticised by researchers engaged in health service research, who emphasise that the complex attributes of health care research require a variety of approaches and methodologies to be employed (Silverman 1993, Murphy et al 1998, Miller and Crabtree 2000).

\section{Research in health care}

Health care research has traditionally been viewed as a positivistic, biomedical domain, with little understanding of the nature of qualitative research. However, health care has much to benefit from the knowledge generation of qualitative strategies (Pope and Mays 2000). The choice of paradigm should, therefore, reflect the question and not the preordained beliefs of the researcher. Having agreed that the research should guide the methodology and not vice versa, it is also worth acknowledging that mixed methodologies are frequently necessary in order to address the complex multiple realities of a research question. However, the differing methods need not hold equal weight in all studies. Murphy et al (1998) illustrated how qualitative research methods may take a series of positions on a continuum from a junior to a senior research approach, depending on the nature of the research.

\section{The combinist perspective}

In order to be able to carry out research within the health care environment, Miller and Crabtree (2000) highlighted the importance of:

$$
\begin{aligned}
& \text {... seeing with three eyes - the biomedical eye, the inward } \\
& \text { searching eye of reflexivity, and a third eye that looks for the } \\
& \text { multiple nested contexts that hold and shape the research } \\
& \text { questions (p611). }
\end{aligned}
$$

With the above premise, Miller and Crabtree (2000) proposed a new 'gold standard' (p613) of clinical research, one in which multiple methods of inquiry (both quantitative and qualitative) were employed. Such a proposal was not the 'fool's gold' offering 'false riches' (Hyde 2004, p90), but a realistic approach to address the complexity of health care research, including occupational therapy. It was conceptualised as a double helix of DNA: on one strand the quantitative methodologies and on the other the qualitative methodologies, with both strands connected by the same research questions (Miller and Crabtree 2000).

The combination of methods is a strongly contested arena and has been described as the separatist vs the combinist debate (Duffy 1987). However, this debate is relatively recent because, prior to the rise of positivism in the 1940s, qualitative and quantitative methods were already used in a collaborative manner (Hammersley and Atkinson 1995). Supporters of the combinist perspective argue that the primary choice of approach, when addressing a research subject, should be based on purely instrumental or pragmatic grounds, with the decision being made on which method would address the question best.

The justification for including qualitative strategies in health care research is further enhanced by an examination of health care policy. The Scottish Consumer Council (1994) recognised the value of qualitative methods when conducting health care research. Furthermore, the Scottish Executive Health Department (2000) clearly endorsed the policy of giving the users of health care services a stronger voice in service development.

\section{Idealism or realism?}

Although the combination of both paradigms is supported by the above theorists on a pragmatic basis, such a position has also been criticised as being unsustainable because each perspective holds a differing view of reality. Hill Bailey (1997) rejected the possibility of combining research approaches as an ontological impossibility because quantitative research was based on 'scientific realism' while qualitative research was based on 'scientific idealistic' assumptions. These positions find their roots in philosophy and can be summarised as follows:

- Scientific realism is 'the belief that our world has an existence independent of our perception of it' (Williams and May 1996, p81)

- Scientific idealism is formed from the belief that the external world consists of symbols that are constructed in the mind (Williams and May 1996, Pope and Mays 2000). Lincoln and Guba (1985) dismissed scientific realism as a 'naive realism' (p84), describing this as the belief that there was a single unequivocal entity which was completely independent of the researcher or the research process. Instead, Lincoln and Guba (1985) proposed that truth was most clearly understood as the best informed and most sophisticated construction on which there was a consensus. Within this construction, the researcher and participants were an integral process. Other qualitative researchers, known as extreme relativists, reject such a proposal and hold that all research perspectives are unique and equally valid. Extreme relativism is generally viewed as untenable in health care, where research is required to be applied to a setting and which results in action in order to enhance care (Pope and Mays 2000). 


\section{Subtle realism}

A further perspective on the philosophical underpinnings of research, known as 'subtle realism', has also been offered (Kirk and Miller 1986, Hammersley 1992). Subtle realists state that all research involves subjective perceptions and observations and concede that different methods will produce different pictures of the participant(s) being studied. Such a stance, however, is not taken to the extent of the extreme relativists (Pope and Mays 2000). Hammersley (1992) and Kirk and Miller (1986) proposed that subjective perceptions and observations did not preclude the existence of independent phenomena and that objects, relationships and experiences could be studied. Therefore, Hammersley's (1992) subtle realist position is compatible with the perspective of combining the research methodologies.

The subtle realist understands that there is no manner in which the researcher can claim to have absolute certainty regarding the findings of his or her research. Rather:

\footnotetext{
...the objective should be the search for knowledge about which we can be reasonably confident. Such confidence will be based upon judgements about the credibility and plausibility of knowledge claims (Murphy et al 1998, p69).
}

This concept has, however, been criticised as having no true ontological basis (Seale 1999). Others (Smith and Heshusius 1986) have argued that subtle realism is a post-positivistic/realist approach, which requires to be defined as such in order to shape the methodological analysis of data coming from a study. Despite such criticisms, the subtle realist approach is increasingly being embraced as a useful research construct in health care (Murphy et al 1998). In their comprehensive review of qualitative research methods, Murphy et al (1998) supported Hammersley's (1992) perspective of subtle realism as a valuable approach to health care research.

\section{Conclusion}

Occupational therapy, as a client-centred and complex intervention, poses significant research challenges. These challenges reach to the ontological and epistemological roots of knowledge. Recent publications have brought these dilemmas to light and various views have been offered as to the best approach to research within the profession.

This opinion piece has argued that it is necessary to use combined research methods in all occupational therapy research and supports the use of the revised gold standard of Miller and Crabtree (2000). Subtle realism has been described and is presented as an important epistemological perspective that is gaining ground within health care research and that offers a useful alternative perspective on the nature of knowledge for research within the profession.

\section{Acknowledgements}

This paper was developed from the first author's doctoral thesis. I am grateful to Professor Alastair Ager for research supervision.

The following institutions supported the study:

- The College of Occupational Therapists, for the Hospital Saving Association Research Degree Scholarship (1999)

- The High Security Psychiatric Services Commissioning Board for the award of a Sir Kenneth Calman Bursary (1999)

- The State Hospital Research Funding Committee (2002)

- The Occupational Therapy Service at The State Hospital for supporting this work through dedicated time.

\section{References}

Bannigan K (2002) EBP, RCTs and a climate of mutual respect. (Letter.) British Journal of Occupational Therapy, 65(8), 391-92.

Bryant W (2004) Numbers in evidence. (Letter.) British Journal of Occupational Therapy, 67(2), 99-100.

Copley J (2002) RCTs: continuing the debate. (Letter.) British Journal of Occupational Therapy, 65(7), 346-47.

Creek J (2003) Occupational therapy defined as a complex intervention. London: College of Occupational Therapists.

Denzin NK, Lincoln YS (2000) Introduction: the discipline and practice of qualitative research. In: NK Denzin, YS Lincoln, eds. Handbook of qualitative research. 2nd ed. Thousand Oaks, CA: Sage, 1-28.

Duffy M (1987) Methodological triangulation: a vehicle for merging quantitative and qualitative research methods. Journal of Nursing Scholarship, 19, 130-33.

Eva G, Paley J (2004) Numbers in evidence. British Journal of Occupational Therapy, 67(1), 47-50.

Hammersley M (1992) What's wrong with ethnography? New York: Routledge.

Hammersley M, Atkinson P (1995) Ethnography: principles in practice. London: Routledge.

Henwood K, Nicholson P (1996) Qualitative research. The Psychologist, 3, 109-10.

Hill Bailey PH (1997) Finding your way around qualitative methods. Journal of Advanced Nursing, 25, 18-22.

Hyde P (2002) RCTs: legitimate research tool or fancy mathematics? (Letter.) British Journal of Occupational Therapy, 65(9), 435-36.

Hyde P (2004) Fool's gold: examining the use of gold standards in the production of research evidence. British Journal of Occupational Therapy, 67(2), 89-93.

Kirk J, Miller M (1986) Reliability and validity in qualitative research. Newbury Park, CA: Sage.

Legg L, Walker M (2002) Let us use randomised controlled trials. (Letter.) British Journal of Occupational Therapy, 65(3), 149.

Lincoln YS (1990) The making of a constructivist: a remembrance of transformations past, the paradigm dialogue. Newbury Park, CA: Sage.

Lincoln YS, Guba EG (1985) Naturalistic inquiry. Newbury Park, CA: Sage.

Lincoln YS, Guba EG (2000) Paradigmatic controversies, contradictions and emerging confluences. In: KN Denzin, YS Lincoln, eds. Handbook of qualitative research. 2nd ed. Thousand Oaks, CA: Sage, 163-88.

MacLean F, Jones D (2002) RCTs: need for wider debate. (Letter.) British Journal of Occupational Therapy, 65(6), 294-95.

Miller WL, Crabtree BF (2000) Clinical research. In: NK Denzin, YS Lincoln, eds. Handbook of qualitative research. Thousand Oaks, CA: Sage, 607-31. 
Murphy E, Dingwall R, Greatbatch D, Parker S, Watson P (1998) Qualitative research methods in health technology assessment: a review of the literature. Health Technology Assessment, 2(16), 1-276.

Pope C, Mays N (2000) Qualitative methods in health research. In: C Pope, N Mays, eds. Qualitative research in health care. 2nd ed. London: British Medical Journal Publishing Group.

Scottish Consumer Council (1994) Consumers: a guide to good practice for the NHS in Scotland. Edinburgh: Scottish Consumer Council.

Scottish Executive Health Department (2000) Our National Health: a plan for action, a plan for change. Edinburgh: Stationery Office.

Seale C (1999) Quality in qualitative research. Qualitative Inquiry, 5, 465-78.

Silverman D (1993) Interpreting qualitative data: methods for analysing talk, text and interaction. London: Sage.
Smith J, Heshusius L (1986) Closing down the conversation: the end of the quantitative-qualitative debate among educational enquirers. Educational Researcher, 15, 4-12.

Williams M, May T (1996) Introduction to the philosophy of social research. London: UCL Press.

\section{Authors}

Edward A S Duncan, PhD, BSc(Hons), DipCBT, Clinical Specialist Occupational Therapist, The State Hospitals Board for Scotland, Carstairs, Lanark, and Postdoctoral Research Fellow, Nursing, Midwifery and Allied Health Professions Research Unit, Department of Nursing and Midwifery, Bowmont Building, University of Stirling, Stirling FK9 4LA. Email: edward.duncan@stir.ac.uk

Margaret M Nicol, PhD, MPhil, TDipCOT, FCOT, Head of Occupational Therapy and Art Therapy, Queen Margaret University College, Edinburgh. 